\title{
A House Hold - Based Survey Of Iodine In Embu County, Kenya
}

\author{
Paul Muriithi Ngari, Mercy Kithinji, John Njagi \\ Department of Health, Embu County \\ DOI: 10.29322/IJSRP.11.10.2021.p11830 \\ http://dx.doi.org/10.29322/IJSRP.11.10.2021.p11830
}

\begin{abstract}
Household salt iodine level monitoring exercise was conducted in 10 schools with a representation from the various zones. The lowlands and highlands each had 4 schools and the urban setup 2 two schools. The exercise in schools was conducted between $8^{\text {th }}$ and $11^{\text {th }}$ June, 2021

Purposive sampling was done to identify sampling zones. Due to agro-climatic and natural characteristics Manyatta and Runyenjes sub-counties were selected to represent the highland zone and urban settings. Mbeere South and Mbeere North represented the lowlands.

Grade three and class five pupils were involved the sampling. Due to the high numbers (enrollment in the targeted classes more than 35 which was the expected sample size per school) systematic random sampling technique was applied to identify the pupils to bring in the samples. A total number of 350 samples were collected.

Out of a total of 350 samples collected and tested using the RTK, only one was found to have low iodine (light blue colour) after both the initial test and the confirmatory test. The rest of the samples (349) were found to have high iodine (dark blue colour).
\end{abstract}

Index Terms- Salt iodine, Embu County, Sub County, Households

\section{INTRODUCTION}

$\mathrm{E}^{\mathrm{n}}$ mbu County is one of the nine counties in Eastern region of the Republic of Kenya and occupies a total area of 2,818 sq.Km. It borders Kirinyaga County to the West, Kitui County to the East, Machakos County to the South, Murang'a County to the South West, Tharaka Nithi County to the North and Meru to the North West. The county is divided into four Sub-counties, namely; Runyenjes, Manyatta, Mbeere South and Mbeere North.

Embu County depicts two distinct areas with different agroclimatic and natural characteristics. The upper area (highlands) around Mount Kenya consists of Runyenjes and Manyatta subcounties, while the lower part (lowlands) consists of Mbeere North and Mbeere South Sub-counties. There are two major Urban Centers, Embu and Runyenjes towns located in Manyatta and Runyenjes sub-counties respectively.

\section{METHODOLOGY}

\section{Sensitization of the Sub County/Field teams}

The field Teams comprised of the Sub- County nutritionists and the sub- county public health officers.

The areas/topics of sensitization were

- Universal Salt Iodization (USI) program in Kenya

- Iodine deficiency in Kenya

- Legislation of salt iodization

- Food fortification in Kenya

- Benefits of food fortification

- Criteria for food fortification vehicle

- Determination of the quality of iodized salt in Kenya at Household level

○ Sampling methodology

- Salt iodine testing using Rapid Testing Kits (RTK)

- Documentation and report writing

\section{SAMPLING}

\section{School selection}

Purposive sampling was done to identify sampling zones. Due to agro-climatic and natural characteristics Manyatta and Runyenjes sub-counties were selected to represent the highland zone and urban settings. Mbeere South and Mbeere North represented the lowlands.

The distribution of the number of schools that were selected per sub-county was done through proportionate sampling. Whereby, the number of public schools per sub-county was factored in. selection of the specific schools was randomly done. Schools that had being engaged in similar previous exercise in the year 2017 and 2019 were excluded from the sampling frame. A total of 10 schools were selected and participated in the exercise.

The head teachers of the sampled schools were briefed on phone and notified the dates that the schools would be visited by the field team.

Distribution of the schools

\begin{tabular}{|l|l|l|}
\hline $\begin{array}{l}\text { Sampling zone } \\
\text { (No. of schools) }\end{array}$ & $\begin{array}{l}\text { Sub-county ( } \\
\text { No. of schools) }\end{array}$ & $\begin{array}{l}\text { Name of the } \\
\text { school }\end{array}$ \\
\hline Highlands (4) & Manyatta (2) & $\begin{array}{l}\text { Kibugu Primary } \\
\text { Kamiu Primary }\end{array}$ \\
\cline { 2 - 3 } & Runyenjes (2) & $\begin{array}{l}\text { Kathuriri } \\
\text { Primary }\end{array}$ \\
\hline
\end{tabular}




\begin{tabular}{|l|l|l|}
\hline \multirow{2}{*}{ Urban (2) } & Manyatta (1) & $\begin{array}{l}\text { Rukuriri } \\
\text { Primary }\end{array}$ \\
& Urban Primary \\
\cline { 2 - 3 } & Runyenjes (1) & $\begin{array}{l}\text { S.A Gikuuri } \\
\text { primary }\end{array}$ \\
\hline \multirow{3}{*}{ Lowlands (4) } & $\begin{array}{l}\text { Mbeere North } \\
(2)\end{array}$ & $\begin{array}{l}\text { Cianyi Primary } \\
\text { Makunguru } \\
\text { Primary }\end{array}$ \\
\cline { 2 - 3 } & $\begin{array}{l}\text { Mbeere South } \\
(2)\end{array}$ & $\begin{array}{l}\text { Kanothi } \\
\text { Primary } \\
\text { J.N Mwonge- } \\
\text { Ndaguma } \\
\text { Primary }\end{array}$ \\
\hline
\end{tabular}

\section{Sensitization of the schools}

In collaboration with the head teachers from the respective sampled primary schools, Sensitization of the pupils was done prior to sample collection and actual day for testing of the samples. The package of the information disseminated included

- Importance of using iodised salt

- Why salt should be tested for iodine

- Request children to pass same information to parents.

Special attention was given to grade three and class five pupils that were to bring in the samples and their respective class teachers. They were sensitized on relevant aspects of sample collection, packaging, handling, labelling and rapid testing.

\section{Salt sampling}

Grade three and class five pupils were involved the sampling. Due to the high numbers (enrollment in the targeted classes more than 35 which was the expected sample size per school) systematic random sampling technique was applied to identify the pupils to bring in the samples. A total number of 350 samples were collected.

\begin{tabular}{|l|l|l|l|l|}
\hline Region & Highlands & Urban & Lowlands & Total \\
\hline $\begin{array}{l}\text { Sample } \\
\text { size }\end{array}$ & $\mathbf{1 4 0}$ & $\mathbf{7 0}$ & $\mathbf{1 4 0}$ & $\mathbf{3 5 0}$ \\
\hline
\end{tabular}

\section{Iodine testing}

Before testing the samples sorting to check for compliance in labeling and adequacy was done by the field officers with assistance from the teachers. A recap on the benefits of iodized salt was done and introduction on how to use the RTK to test for iodine levels. The exercise was conducted in the presence of the pupils and the teachers.

\section{FINDINGS}

1. Out of a total of 350 samples collected and tested using the RTK, only one was found to have low iodine (light blue colour) after both the initial test and the confirmatory test. The rest of the samples (349) were found to have high iodine (dark blue colour). From this findings, the County percentage of Households with iodized salt is therefore $\mathbf{1 0 0 \%}$ as computed using the formula below

No. of samples with positive (low and high iodine) test results $\underline{\text { RTK }} \times 100$

Total of samples collected and tested

2. Some samples were darker than others depicting different levels of the iodine. From the discussions with the pupils storage of salt was an issue, it was reported that salt was stored uncovered.

3. Majority of the households $96.6 \%$ use Ken salt brands and a minority (3.2\%) consumed other brands which include sea salt, Kay salt, Nutra meal and sun salt. Only one brand $(0.2 \%)$ was unknown.

4. The most common source of the salt consumed by the households was the shop, followed by supermarkets.

\section{CONSTRAINTS}

The following constraints/challenges were experienced during the survey

- Due to increase in quantity of salt required (4 tablespoons) some pupils could not be able to bring enough salt and thus brought amounts below what was required.

- Low enrollment of pupils from the targeted classes and where they were below the required number of 35 samples the grade 3 and class five pupils were combined together

- A challenge working with grade 3 pupils since most of them could not properly comprehend the information, had challenges in labelling the envelopes.

- The exercise took place during mid-term exams hence limited time for the sensitization and testing in the schools

- Despite demonstration on how to zip lock the sample collection envelops most pupils were not able to lock hence some salt poured out.

- Some envelopes also had faulty zip locks and only a limited number of the envelopes was provided

- It was difficult to follow the Covid -19 guidelines on distancing though at least all the pupils involved wore face masks

\section{RECOMMENDATIONS}

Based on this Survey findings and constraints during the exercise, we wish to make the following recommendations;

1. Need to compensate the parents for the amount of salt used as a sample therefore consider allocating resource to replenish salt at household level as the sample size required is a lot

2. Involvement of any other upper-level classes instead of grade 3 


\section{CONCLUSION}

3. Provide adequate extra envelopes for the eventuality that some are destroyed or are faulty

4. The exercise should be done annually. Last activity conducted in 2019.

5. Conduct market level monitoring to target other brands of salts that could be stocked in supermarkets and other outlets

6. Continuous education on importance of using/demanding for iodized salt, storage of salt at household level to maintain the potency.

7. Feed back to the county/sub-counties and respective schools of the results from NPHL.
Households in Embu County have access to and consume iodized table salt.

\section{AUTHORS}

First Author - Paul Muriithi Ngari, Department of Health, Embu County

Second Author - Mercy Kithinji, Department of Health, Embu County

Third Author - John Njagi, Department of Health, Embu County 